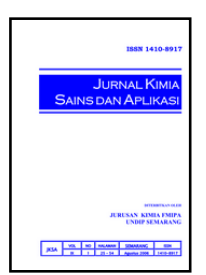

\title{
Pengaruh Berat Molekul Kitosan terhadap Efisiensi Enkapsulasi BSA (Bovine Serum Albumin) Menggunakan Agen Crosslink Na- TPP
}

\author{
Nastiti $^{a}$, Parsaoran Siahaan ${ }^{a^{*}}$ \\ a Physical Chemistry Laboratory, Chemistry Department, Faculty of Sciences and Mathematics, Diponegoro University, Jalan Prof. \\ Soedarto, Tembalang, Semarang \\ * Corresponding author: siahaan.parsaoran@live.undip.ac.id
}

\section{Article Info}

Keywords:

Chitosan, BSA, NaTPP, encapsulation efficiency, molecular weight, interaction

\section{Abstract}

This research has been done about effect of the molecular weight chitosan on encapsulation efficiency of BSA (Bovine Serum Albumin) using Na-TPP as crosslink agent. This research aims to determine the effect of molecular weight chitosan and addition of crosslink agent Na-TPP toward encapsulation efficiency of BSA, and predict the interactions that occur between chitosan and BSA by molecular modeling. Molecular weight chitosan can be decrease by hydrolysis with $\mathrm{HCl} 0.5 \mathrm{~N}$ and encapsulation efficiency chitosan of BSA is measurement-using spectrophotometer UV-Vis at $\lambda 278 \mathrm{~nm}$. Interaction between chitosan and BSA by optimization and determination of interaction energy by using ab initio methods and molecular docking. Molecular weight of initial chitosan and hydrolyzed chitosan $\mathrm{HCl} 0.5 \mathrm{~N}$ are $1.666 \times 10^{5} \mathrm{Da}$ and $1.277 \times 10^{3} \mathrm{Da}$. Encapsulation efficiency of hydrolyzed chitosan greater than initial chitosan, $57.111 \%$ with the addition of Na-TPP becomes $61.751 \%$. It can be concluded the chitosan with lower molecular weight and the presence of Na-TPP as a crosslink agent can enhancing the effiency encapsulation. Interaction between chitosan and BSA show by the interaction energy between chitosan trimer and glutamine at $-74.765 \mathrm{~kJ} \mathrm{~mol}^{-1}$, meanwhile with molecular docking is $-13.221 \mathrm{~kJ} \mathrm{~mol}^{-1}$. Calculation with molecular docking, energy interaction of trimer chitosan with glutamine in chain A and B of BSA are $-12.301 \mathrm{~kJ} \mathrm{~mol}^{-1}$ and $-9.665 \mathrm{~kJ} \mathrm{~mol}^{-1}$.

\section{Abstrak}

Telah dilakukan penelitian tentang pengaruh berat molekul kitosan terhadap efisiensi enkapsulasi BSA (bovine serum albumin) menggunakan agen crosslink Na-TPP. Penelitian ini bertujuan menentukan pengaruh berat molekul kitosan dan adanya agen crosslink Na-TPP terhadap efisiensi enkapsulasi BSA, serta memprediksi interaksi yang terjadi antara kitosan dan BSA menggunakan pemodelan molekul. Berat molekul kitosan diperkecil dengan metode hidrolisis dengan $\mathrm{HCl} 0,5 \mathrm{~N}$ dan efisiensi enkapsulasi kitosan terhadap BSA ini ditentukan dengan pengukuran menggunakan spektrofotometer UV-Vis pada $\lambda 278 \mathrm{~nm}$. Interaksi antara kitosan dan BSA dapat diketahui dengan optimasi dan penentuan energi interaksi dengan menggunakan metode $a b$ initio dan molecular docking.. Berat molekul kitosan awal dan kitosan hasil hidrolisis $\mathrm{HCl} 0,5 \mathrm{~N}$ yaitu $1,666 \times 10^{5}$ Da dan $1,277 \times 10^{3}$ Da. Efisiensi enkapsulasi kitosan hasil hidrolisis lebih besar dibandingkan kitosan awal yaitu 57,111\%, dengan penambahan NaTPP menjadi $61,751 \%$. Disimpulkan bahwa penggunaan kitosan hasil hidrolisis dengan berat molekul rendah dan adanya Na-TPP sebagai agen crosslink mampu meningkatkan kemampuan enkapsulasi kitosan. Interaksi antara kitosan dan BSA ditunjukkan dengan diperolehnya energi interaksi antara trimer kitosan dan glutamin dengan menggunakan $a b$ initio sebesar $74,765 \mathrm{~kJ} \mathrm{~mol}^{-1}$, sedangkan dengan molecular docking adalah $-13,221 \mathrm{~kJ} \mathrm{~mol}^{-1}$. Dengan molecular docking juga diperoleh energi interaksi antara trimer kitosan dengan glutamin pada rantai $\mathrm{A}$ dan B dari BSA sebesar $-12,301 \mathrm{~kJ} \mathrm{~mol}^{-1}$ dan $-9,665 \mathrm{~kJ} \mathrm{~mol}^{-1}$. 


\section{Pendahuluan}

Drug Delivery merupakan suatu sistem pembawa obat (agen teraupetik) atau zat yang mudah terdegradasi, dengan adanya suatu sistem yang dapat melindungi agen teraupetik dari lingkungan yang dapat mendegradasinya maka agen teaupetik tersebut dapat sampai ke tempat yang di targetkan (sel target). Sistem pengiriman obat (drug delivery) terdiri dari tiga komponen: agen terapeutik, sebuah bagian penargetan (sel target), dan sistem pembawa, dimana agen terapeutik ini dapat dimasukkan dalam sistem secara penyerapan pasif atau konjugasi kimia [1].

Sistem pembawa atau carrier yang sering digunakan adalah kitosan. Kitosan merupakan polimer kationik yang dapat larut dalam asam organik seperti asam asetat dan asam format. Kitosan memiliki sifat nontoksik dan biokompatibel, sifat-sifat kitosan ini dipengaruhi oleh derajat deasetilasi (DD) dan berat molekul, dimana gugus amina dalam kitosan merupakan pembawa sifat khas [2, 3]. Gugus amina ($\mathrm{NH}_{2}$ ) dalam kitosan menyebabkan terjadinya mekanisme seperti ikatan silang kimia, ikatan silang ionik, dan ion kompleksasi. Ikatan silang (crosslink) adalah ikatan yang menghubungkan antar molekul polisakarida. Crosslink dapat terjadi antara kation kitosan dengan protein maupun dengan polianion multivalen seperti TPP (tripolipospat) yang memiliki kemampuan untuk membentuk gel [4]. Adanya crosslink antara TPP dan kitosan ini menyebabkan kitosan menunjukkan hasil yang lebih tinggi dalam enkapsulasi [5].

Enkapsulasi dapat juga menggunakan kitosan dengan berat molekul yang rendah (memiliki rantai yang lebih pendek), karena gugus amina $\left(-\mathrm{NH}_{2}\right)$ akan lebih mudah terprotonasi,

Sehingga dapat berinteraksi dengan molekul protein yang akan dienkapsulasi, sedangkan untuk kitosan dengan berat molekul besar gugus amina sulit untuk terprotonasi [2]. Salah satu metode untuk memperpendek rantai kitosan adalah dengan proses hidrolisis. Hasil yang diperoleh dari proses hidrolisis adalah kitosan dengan berat molekul yang lebih kecil (rantai kitosan lebih pendek), sehingga memungkinkan untuk meningkatkan efisiensi enkapsulasi kitosan. Enkapsulasi dilakukan dengan metode presipitasi, yaitu dengan mengendapkan kembali kitosan telah berinteraksi atau menjebak molekul protein dengan penambahan larutan basa. Suatu interaksi yang terjadi antara dua molekul dapat diprediksi dengan melihat energi interaksi antara kedua molekul dengan menggunakan pemodelan molekul. Energi interaksi ini merupakan landasan penting dalam memahami suatu molekul maupun atom dalam suatu sistem kimia. Metode yang dapat digunakan dalam menentukan energi interaksi antar molekul adalah $a b$ initio dengan memperhitungkan interaksi setiap elektron dalam suatu molekul dan molecular docking hanya memperhitungkan titik muatan dalam suatu atom atau molekul.
Pada penelitian ini dilakukan enkapsulasi protein BSA (Bovine Serum Albumin) sebagai model molekul protein menggunakan kitosan dengan berat molekul berbeda dan enkapsulasi dengan menggunakan agen crosslink Na-TPP untuk meningkatkan efisiensi enkapsulasi. Serta menentukan energi interaksi yang dapat terjadi antara kitosan dan BSA dengan menggunakan metode $a b$ initio dan molecular docking.

\section{Metode Penelitian}

\section{Alat dan Bahan}

Peralatan yang digunakan dalam penelitian ini adalah peralatan gelas laboratorium kimia, magnetic stirer, viskosimeter Oswald, Multimeter HANNA HI991301 ( $\mathrm{pH}$ meter\& konduktometer), sentrifus, Spektrofotometer UV-Vis T60U Spectrometer, FTIR IRPrestige-21 (SHIMADZU), neraca analitik, seperangkat komputer berbasis linux dan windows. Bahan yang digunakan dalam penelitian ini adalah kitosan dari IPB, kitosan medium (merck), Na-TPP p.a dari Sigma-Aldrich, NaOH p.a dari Sigma-Aldrich, $\mathrm{HCl}$ p.a, asam asetat glasial p.a, BSA dari Sigma-Aldrich, $\mathrm{NaCl}$ p.a.

\section{Hidrolisis Kitosan}

Larutan kitosan dari IPB (awal) 2\% (w/v) dibuat menggunakan pelarut asam asetat glasial $1 \%$. Proses hidrolisis menggunakan asam klorida $(\mathrm{HCl}) \quad 0,5 \mathrm{~N}$ dengan waktu hidrolisis selama 1 jam. Penambahan larutan $\mathrm{NaOH} 1 \mathrm{~N}$ sampai $\mathrm{pH}$ larutan menjadi 7 dan dilakukan proses dekantasi dan pengukuran konduktivitas sampai konduktivitas larutan mendekati konduktivitas aquades.

Penentuan berat molekul kitosan dengan mengukur viskositas menggunakan viskometer oswald. Kitosan yang akan diukur viskositas dilarutkan dalam pelarut campuran antara asam asetat glasial $1 \%$ dan $\mathrm{NaCl} 2 \mathrm{M}$ (3:1). Berat molekul di hitung dengan persamaan Markhouwink dengan viskositas intrinsik yang dihitung menggunakan persamaan Huggins [6].

\section{Enkapsulasi BSA}

Proses ekapsulasi BSA ini dilakukan dengan menggunakan kitosan konsentrasi 20mg/20mL [7] dan BSA 2000ppm dengan perbandingan volume 1:1, dan larutan campuran disentrufuse selama 10 menit dengan kecepatan 60orpm. Penambahan $\mathrm{NaOH}$ sampai $\mathrm{pH}$ menjadi 7 untuk mendapatkan kitosan yang telah menjebak molekul BSA dan dilakukan sentrifuse selama 30 menit dengan kecepatan $6000 \mathrm{rpm}$. Dan dilakukan proses enkapsulasi BSA 2000 ppm dengan menambahkan Na-TPP 0,1\% sebagai agen crosslink pada larutan kitosan. Efisiensi enkapsulasi di hitung dengan:

$$
\mathrm{EE}(\%)=\frac{[\mathrm{BSA}] \text { awal }-[\mathrm{BSA}] \text { sisa }}{[\mathrm{BSA}] \text { awal }} \times 100 \%
$$

Dimana konsentrasi/banyaknya BSA sisa ini diperoleh dengan mengukur banyaknya BSA yang ada di filtrat hasil pemisahan dengan spektofotometer UV-Vis pada panjang gelombang $278 \mathrm{~nm}$, sesuai dengan literatur yang menyatakan BSA dapat terukur pada 
panjang gelombang 280nm [8]. Persamaan linier kurva standar yang diperoleh adalah:

$$
[\mathrm{BSA}]_{\mathrm{sisa}}=1,62016423 \mathrm{~A}+1,37332
$$

\section{Pemodelan Molekul}

Pemodelan molekul dilakukan dengan software gaussian $(\mathrm{QM})$ dan autodock $(\mathrm{MM})$, yang dihitung adalah energi interaksi antara trimerkitosan dengan asam amino glutamin (salah satu penyusun BSA). Basis set yang digunakan pada software gaussian adalah RHF 6-31G(d,p) dan software autodock glutamin berperan sebagai ligan dan trimer kitosan sebagai makromolekul, running dilakukan $150 x$.

\section{Hasil dan Pembahasan}

\section{Hidrolisis Kitosan}

Kitosan awal dan hasil hidrolisis menggunakan $\mathrm{HCl}$ $0,5 \mathrm{~N}$ diukur viskositasnya, dan untuk mengetahui berat molekul kitosan tersebut dilakukan perhitungan menggunakan persamaan Huggin dengan menggunakan software mathcad. Berat molekul kitosan awal yang diperoleh adalah $1,666.10^{5}$ Da sedangkan kitosan yang telah dihidrolisis adalah sebesar $1,277 \times 10^{3}$ Da, Adanya penurunan berat molekul ini menunjukkan bahwa $\mathrm{HCl}$ 0,5 N mampu memutuskan ikatan glikosidik yang ada dalam polimer kitosan, yang menyebabkan rantai polimer kitosan memendek dan viskositasnya menurun (berat molekulnya rendah). Hasil pengukuran berat molekul kitosan medium (merck) yaitu 3,418 $\times 10^{3}$ $\mathrm{Da}$, dan kitosan medium ini digunakan sebagai pembanding dalam enkapsulasi BSA.

\section{Enkapsulasi BSA}

Enkapsulasi BSA pada kitosan awal dan kitosan hasil hidrolisis dilakukan untuk mengetahui pengaruh berat molekul dalam kemampuan mengenkapsulasi protein (efisiensi enkapsulsai), BSA digunakan sebagai model molekul protein. Dan untuk mengetahui interaksi anatara kitosan dan BSA dilakukan pengukuran konduktivitas. Adanya interaksi antara kitosan, TPP dan BSA dapat dijelaskan dengan konduktivitas dimana konduktivitas kitosan hasil hidrolisis, BSA 2000ppm dan Na-TPP 0,1\% adalah $589 \mu \mathrm{S}, 51 \mu \mathrm{S}$ dan $1097 \mu \mathrm{S}$. Konduktiviitas kitosan hasil hidrolisis mengalami penurunan setelah penambahan BSA menjadi $412 \mu \mathrm{S}$, hal ini menunjukkan adanya interaksi antara kitosan dan BSA (kation dari kitosan berinteraksi dengan anion dari BSA).

Proses enkapsulasi menggunakan metode presipitasi (pengendapan) dengan $\mathrm{NaOH}$ ini menghasilkan endapan kitosan yang telah menjebak BSA dan filtrat yang mengandung BSA yang tidak terenkapsulasi oleh kitosan. Filtrat ini dianalisis dengan spektrofotometer UV-Vis pada panjang gelombang 278nm. Hasil pengukuran dan perhitungan efisiensi enkapsulasi (EE) ditampilkan dalam tabel 1.
Tabel 1: Hasil penentuan berat molekul kitosan

\begin{tabular}{cccc}
\hline Sampel & Abs & {$\left[\mathrm{BSA}_{\text {sisa }}\right]$} & $\mathrm{EE}(\%)$ \\
\hline k.awal(IPB) & 0,703 & 1145,973 & 42,701 \\
k.Medium & 0,832 & 1356,006 & 32,199 \\
k.hidrolisis & 0,469 & 764,9823 & 61,751 \\
\hline
\end{tabular}

Pada tabel 1 dapat dilihat kitosan hasil hidrolisis yang memiliki berat molekul lebih rendah dari kitosan awalnya memiliki efisiensi enkapsulasi lebih besar, hal ini disebabkan karena rantai kitosan yang lebih pendek (BM kecil) ini gugus amina dari kitosan akan lebih mudah terprotonasi yang mengakibatkan semakin mudah untuk berinteraksi dengan molekul BSA sehingga BSA yang terenkapsulasi akan semakin besar dibandingkan dengan kitosan yang memiliki rantai panjang. Namun pada kitosan medium efisiensi enkapsulasi lebih kecil dibandingkan kitosan awal meskipun berat molekul lebih kecil dari kitosan awal hal ini disebabkan karena kitosan awal memiliki derajat deasetilasi (DD) yang lebih besar dibandingkan kitosan medium yaitu untuk kitosan awal 71,9 dan kitosan medium 60,9, hasil ini sesuai dengan penelitian yang dilakukan oleh Gan dan Wang [4] bahwa semakin besa DD maka efisiensi enkapsulasi juga semakin besar.

Selain dengan memperpendek rantai kitosan untuk meningkatkan efisiensi enkapsulasi dari kitosan dapat digunakan suatu agen crosslink seperti TPP. Dilakukan penambahan Na-TPP pada proses enkapsulasi, adanya interaksi antara Kitosan dan Na-TPP ditunjukkan oleh konduktivitas kitosan hasil hidrolisis turun menjadi 506 $\mu S$, penambahan BSA mengalami penurunan kembali menjadi $402 \mu S$, ini menunjukkan bahwa adanya interaksi antara kitosan dan Na-TPP dan juga BSA. Efisiensi enkapsulasi dengan menggunakan Na-TPP lebih besar dibandingkan tanpa menggunakan Na-TPP, sebagaimana ditunjukkan pada gambar 1.

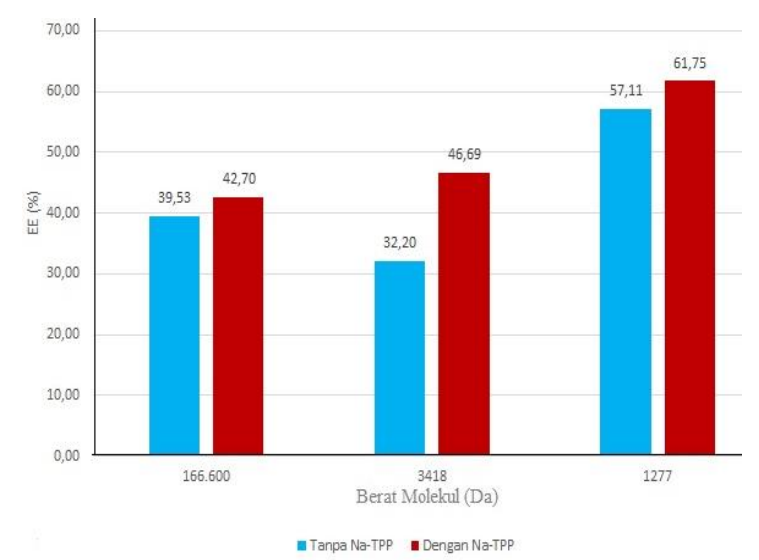

Gambar 1. Efisiensi enkapsulsi kitosan awal dan kitosan hasil hidrolisis dengan maupun tanpa menggunkan

$$
\mathrm{Na}-\mathrm{TPP}
$$

Dari gambar 1 dapat dilihat bahwa penambahan NaTPP sebagai agen crooslink dapat meningkatkan efisiensi enkapsulasi dari kitosan dalam mengenkapsulasi BSA sebesar $4 \%$, Na-TPP ini dapat meningkatkan kemampuan enkapsulsi dari kitosan dengan menrenggangkan ikatan antar rantai kitosan , sehingga 
menyediakan tempat untuk menjebak molekul BSA, selain itu dengan diduga merenggangnya jarak antar rantai kitosan ini menyebabkan gugus amina yang belum terprotonasi akan terprotonasi membentuk $\mathrm{NH}_{3}{ }^{+}$yang dapat meningkatkan banyaknya molekul BSA yang dapat berinteraksi dengan kitosan sehingga efisiensi enkapsulasinya meningkat.

\section{Analisis FTIR}

Hasil karakterisasi FTIR kitosan sebelum dan setelah proses hidrolisis menunjukkan tidak adanya berubahan yang signifikan pada peak-peak yang menunjukkan gugus fungsi khas yang ada si kitosan yang di tunjukkan pada gambar 2.

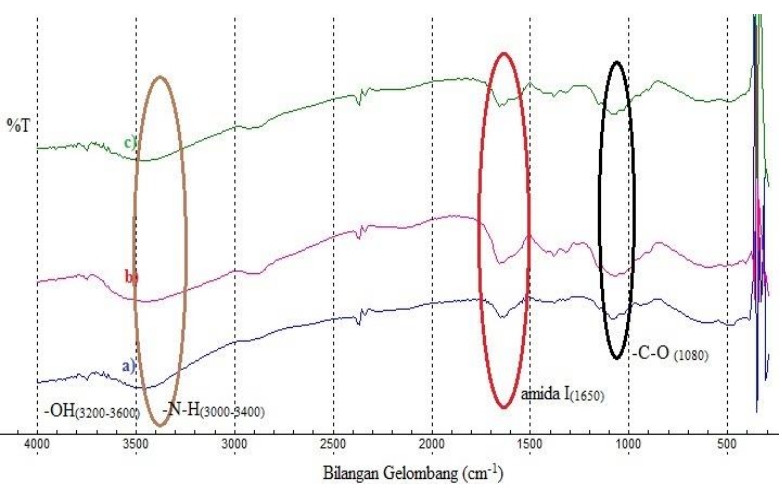

Gambar 2. Hasil FTIR (a) kitosan awal (b) kitosan hidrolisis $0,5 \mathrm{~N}$ (c) kitosan medium

Pada gambar 2 menunjukkan adanya gugus amida I (-CO-NH-), yang dalam kitosan adalah gugus asetil, dan -C-O pada $1080 \mathrm{~cm}^{-1}$ menunjukkan bahwa dalam kitosan terdapat ikatan antara $-\mathrm{C}-\mathrm{O}$ yaitu pada ikatan glikosidik yang menghubunkan monomer-monomer kitosan. Selain itu pada daerah 3000-3600 menunjukkan adanya ikatan hidrogen dalam struktur kitosan, dimana dalam monomer kitosan (glukosamin) terdapat gugus $-\mathrm{OH}$ dan juga $-\mathrm{NH}_{2}$.

Secara kualitatif adanya molekul BSA yang terjebak/terenkapsulasi oleh kitosan dapat ditunjukkan dengan data FTIR dengan menlihat adanya peak-peak baru.

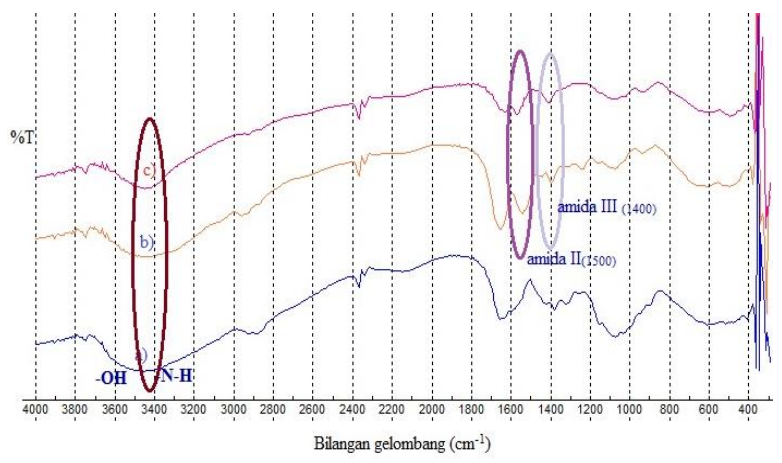

Gambar 3. Hasil FTIR (a) kitosan hidrolisis 0,5N (b)BSA dan (c) kitosan hidrolisis $0,5 \mathrm{~N}+\mathrm{BSA}$

Pada gambar 3 munculnya peak baru yaitu adanya gugus amida II dan amida III (khas untuk protein) yang ada pada BSA pada bilangan gelombang 1566,20 $\mathrm{cm}^{-1}$ dan $1473 \mathrm{~cm}^{-1}$. Ini menunjukkan bahwa kitosan hasil hidrolisis ini telah mengkapsul molekul BSA. Sedangkan hasil enkapsulasi BSA oleh kitosan dengan adanya penambahan Na-TPP ditunjukkan pada gambar 4 .

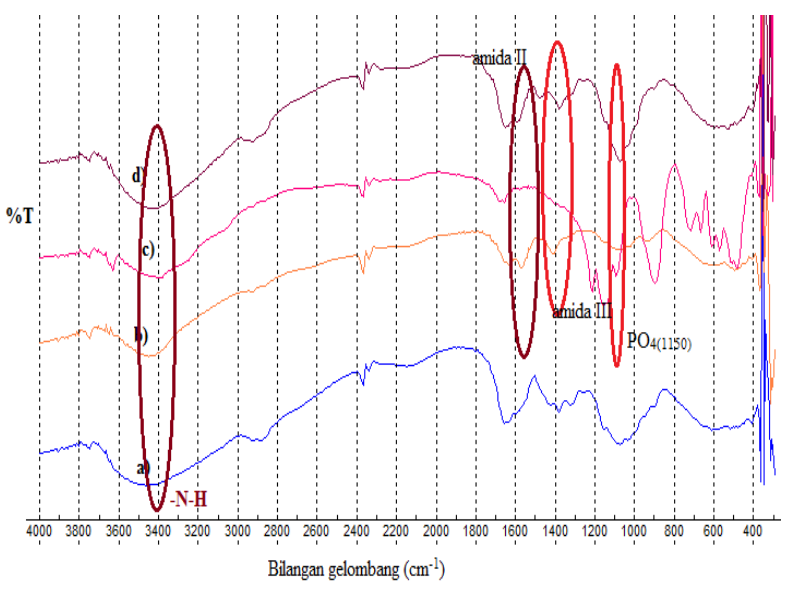

Gambar 4. Hasil FTIR (a) kitosan hidrolisis 0,5N; (b) kitosan hidrolisis $0,5 \mathrm{~N}+\mathrm{BSA}$; (c) Na-TPP d) kitosan hidrolisis $0,5 \mathrm{~N}+\mathrm{Na}-\mathrm{TPP}+\mathrm{BSA}$

Adanya gugus fosfat pada bilangan gelombang 1100 $\mathrm{cm}^{-1}$ (Michele R. Dkk, 1999) ditunjukkan pada gambar 4 d), Pada bilangan gelombang $3440 \mathrm{~cm}^{-1}$ gambar $4 \mathrm{~d}$ ) puncaknya semakin tinggi (\%T rendah) dan melebar dibandingkan pada gambar $4 \mathrm{~b}$ ), ini menunjukkan bahwa adanya penambahan gugus - $\mathrm{NH}$ yang berasal dari BSA, karena semakin banyak BSA yang terperangkap di dalam kitosan.

\section{Pemodelan Molekul}

Molekul yang digunakan dalam pemodelan ini adalah trimer kitosan yang mewakili kitosan dan glutamin, dimana glutamin merupakan salah satu asam amino penyusun BSA. Dengan metode $a b$ initio dilakukan optimasi dengan teori dan basis set RHF 6-31G (d,p) dengan perintah "opt" sehingga diperoleh energi sebesar $-6,215.10^{6} \mathrm{~kJ} \mathrm{~mol}^{-1}$

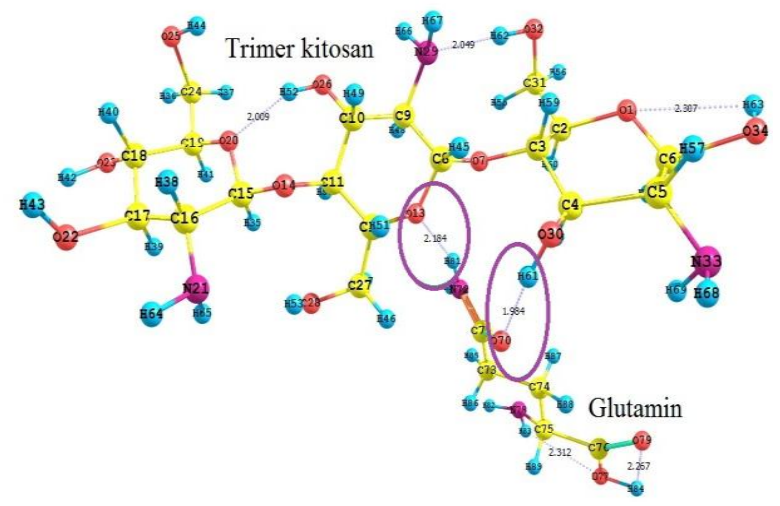

Gambar 5. Interaksi trimer kitosan dan glutamin dengan metode $a b$ initio

Dari gambar 5 hasil optimasi interaksi trimer kitosan dan glutamin dapat diketahui adanya 2 ikatan hidrogen yang terjadi antara atom $\mathrm{O}_{13}$ dari trimer kitosan dengan $\mathrm{H}_{81}$ (yang berikatan dengan atom $\mathrm{N}$ ) pada glutamin dengan jarak interaksi 2,18 $\AA$, dan atom $\mathrm{H}_{61}$ dari trimer kitosan dengan $\mathrm{O}_{70}$ dari glutamin dengan 
jarak interaksi 1,98 ̊̊. Dua ikatan hidrogen berada pada gugus amida I yang ada di glutamin, ini dapat membuktikan bahwa adanya interaksi antara kitosan dengan gugus amida I pada glutamin. energi interaksi antara trimer kitosan dengan glutamin sebesar $-74,765$ $\mathrm{kJ} \mathrm{mol}^{-1}$. Dilihat dari besarnya energi interaksi kedua molekul berada di bawah $418 \mathrm{~kJ} \mathrm{~mol}^{-1}$ dan jarak interaksi dua molekul tersebut adalah mendekati $2 \AA$, sehingga dapat dikatakan bahwa interaksi yang terjadi adalah interaksi non kovalen. Dan interaksi yang terjadi antara kedua molekul adalah ikatan hidrogen. Sedangkan dengan menggunakan molecular docking diperoleh energi interaksi sebesar -13,221 $\mathrm{kJ} \mathrm{mol}^{-1}$, dan menunjukkan adanya interaksi antara trimer kitosan dan glutamin.

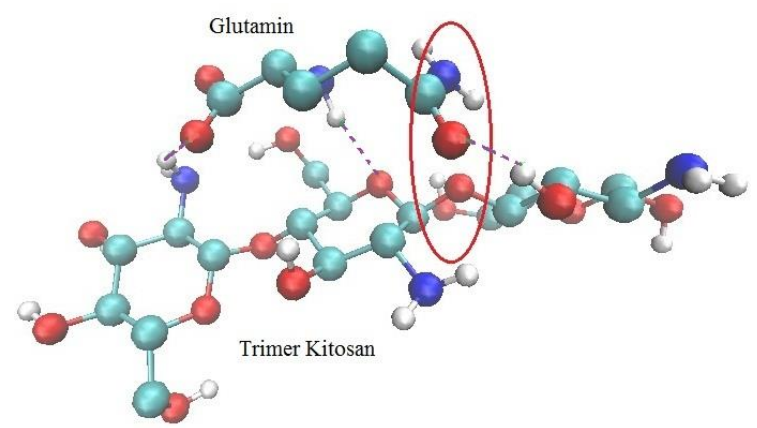

Gambar 6. Interaksi trimer kitosan dan glutamin dengan metode molecular docking

Pada gambar 6 menunjukkan adanya 3 ikatan hidrogen yang terbentuk antara trimer kitosan dan glutamin. Tetapi energi interaksi dengan molecular docking ini lebih rendah dibandingkan energi interaksi pada $a b$ initio hal ini disebabkan karena pada metode molecular docking ini yang diperhitungkan adalah titik muatan dari molekulnya, sedangkan metode $a b$ initio memperhitungkan interaksi yang terjadi di setiap elektron yang menyusun molekulnya. Molecular docking hanya memperhitungkan titik muatan molekul maka perhitungan (penentuan energi interaksi) dapat berlangsung lebih cepat untuk molekul yang besar sehingga dengan metode molecular docking ini dapat di gunakan untuk menentukan energi interaksi antara trimer kitosan dan BSA. BSA ini terdiri dari 2 rantai yaitu A dan B, sehingga dilakukan interaksi antara trimer kitosan dan glutamin yang ada di rantai BSA A maupun B.

Energi interaksi yang terjadi antara glutamin 33 (urutan asam amino ke-33) pada rantai A BSA dan trimerkitosan sebesar $-12,301 \mathrm{~kJ} \mathrm{~mol}^{-1}$ dengan adanya 2 ikatan hidrogen yang terbentuk. Energi interaksi tersebut tidak jauh berbeda dengan energi interaksi antara trimer kitosan dengan glutamin dengan metode molecular docking. Energi interaksi tersebut merupakan energi terendah dari 150 yang diperoleh pada konformasi ke-80. Pada konformasi ke-80 ini gugus amida I dari glutamin berdekatan dengan gugus C-O pada trimer kitosan ditunjukkan pada gambar 7 .

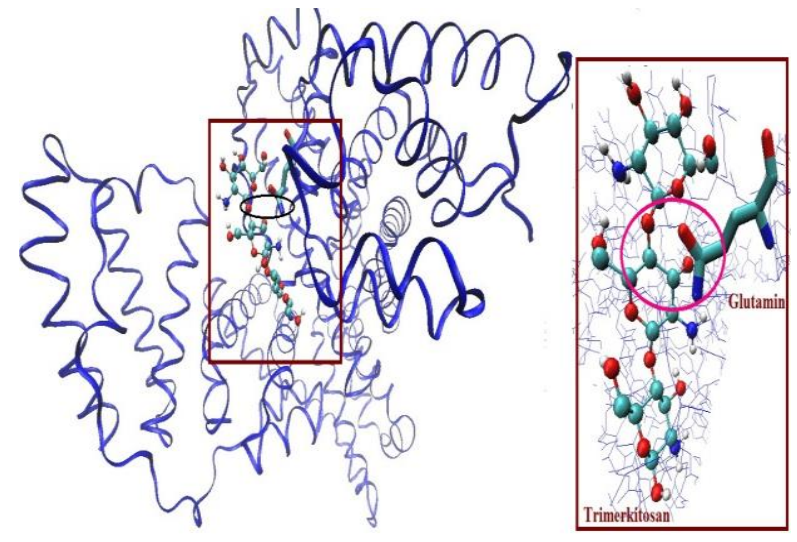

Gambar 7. Hasil docking Gln33 (BSA-A)...trimer kitosan conf 80

Sedangkan untuk interaksi yang terjadi antara glutamin 94 (urutan asam amino ke-94) pada rantai B BSA dan trimer kitosan energi interaksi terendah diperoleh pada running ke-5 yaitu sebesar -9,665 kJ $\mathrm{mol}^{-1}$. Pada gambar 8 juga menunjukkan bahwa interaksi yang terjadi antara trimer kitosan (gugus $-\mathrm{C}-$ O) dan glutamin BSA (gugus amida I). Energi interaksi pada rantai $\mathrm{B}$ ini lebih kecil dibandingkan pada perhitungan sebelumnya pada konformasi ke-5 tidak ada ikatan hidrogen yang terbentuk.

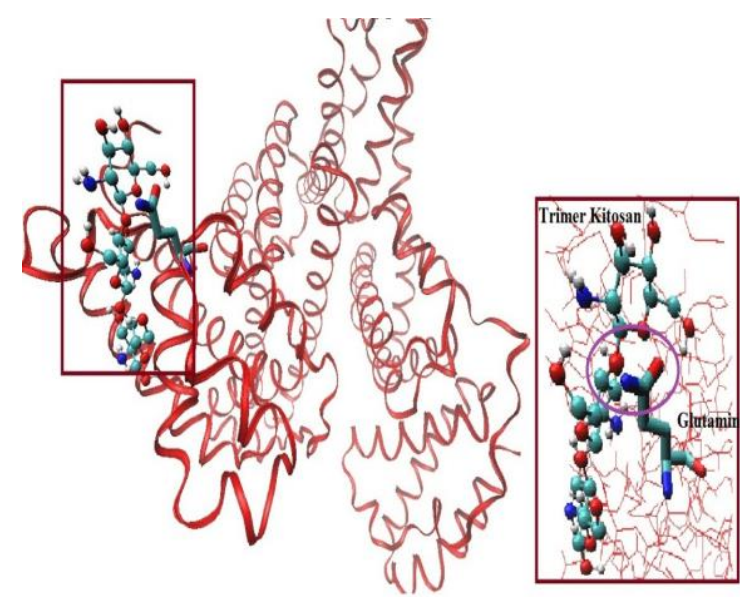

Gambar 8. Hasil docking Gln94 (BSAB)....trimerkitosan-conf 5

Hasil dari kedua metode pemodelan ini menunjukkan bahwa interaksi antara trimer kitosan dan glutamin terjadi pada gugus amida I pada glutamin dengan gugus $-\mathrm{C}-\mathrm{O}$ pada trimer kitosan dan energi interaksi yang dalam range energi interaksi non-kovalen [9]. Ditinjau dari energi interaksinya maka antara kitosan dan BSA ini memenuhi syarat dalam sistem drug delivery, dimana interaksi yang terjadi tidak terlalu kuat sehingga BSA tersebut dapat dilepaskan (release).

\section{Kesimpulan}

Hasil penelitian menunjukkan bahwaefisiensi enkapsulasi kitosan terhadap BSA dapat ditingkatkan dengan memperkecil berat molekul dan dengan penambahan agen crosslink Na-TPP. Efisiensi enkapsulasi tertinggi pada kitosan hasil hidrolisis dengan berat molekul $1,277 \times 10^{3}$ Da yaitu $57,11 \%$ menjadi 
$61,75 \%$ dengan penambahan Na-TPP. Interaksi antara kitosan dan BSA ditunjukkan dengan hasil perhitungan energi interaksi antara trimer kitosan dan glutmin dengan metode $a b$ initio sebesar $-74,765 \mathrm{~kJ} \mathrm{~mol}^{-1}$, sedangkan dengan molecular docking -13,221 kJ mol-1. Dengan molecular docking diperoleh energi interaksi antara trimer kitosan dan glutamin yang ada pada rantai A maupun B di BSA sebesar sebesar $-12,301 \mathrm{~kJ} \mathrm{~mol}^{-1}$ dan $-9,665 \mathrm{~kJ} \mathrm{~mol}^{-1}$.

\section{Daftar Pustaka}

[1] Himanshu Patel, RT Vashi, Treatment of Textile Wastewaterby Adsorption and Coagulation, Journal of Chemistry, 7, 4, (2010) 1468-1476

[2] Hui-Chia Yang, Min-Hsiung Hon, The effect of the molecular weight of chitosan nanoparticles and its application on drug delivery, Microchemical Journal, 92, $1, \quad$ (2009) $\quad 87-91$ http://dx.doi.org/10.1016/j.microc.2009.02.001

[3] Mike TL Tobing, Nor Basid Adibawa Prasetya, Khabibi Khabibi, Peningkatan Derajat Deasetilasi Kitosan dari Cangkang Rajungan dengan Variasi Konsentrasi $\mathrm{NaOH}$ dan Lama Perendaman, Jurnal Kimia Sains dan Aplikasi, 14, 3, (2011) 83-88

[4] Quan Gan, Tao Wang, Chitosan nanoparticle as protein delivery carrier-Systematic examination of fabrication conditions for efficient loading and release, Colloids and Surfaces B: Biointerfaces, 59, 1, (2007) 24-34 http://dx.doi.org/10.1016/j.colsurfb.2007.04.009

[5] Jae Hyung Park, Gurusamy Saravanakumar, Kwangmeyung Kim, Ick Chan Kwon, Targeted delivery of low molecular drugs using chitosan and its derivatives, Advanced Drug Delivery Reviews, 62, 1, (2010) 28-41 http://dx.doi.org/10.1016/j.addr.2009.10.003

[6] Moo-Yeal Lee, Figen Var, Yoshitsune Shin-ya, Toshio Kajiuchi, Ji-Won Yang, Optimum conditions for the precipitation of chitosan oligomers with DP 5-7 in concentrated hydrochloric acid at low temperature, Process Biochemistry, 34, 5, (1999) 493$500 \quad$ http://dx.doi.org/10.1016/S00329592(98)00116-2

[7] Parsaoran Siahaan, Cynthia L Radiman, Susanto Imam Rahayu, Muhamad A Martoprawiro, Dieter Ziessow, Molecular Interaction Between Benzonitrile and Hexamethylphosphoric Triamide by $13 \mathrm{C}$ NMR $\mathrm{T} 1$ Relaxation Time Studies and $\mathrm{AB}$ Initio QM Calculations: Extended Investigation, Indonesian Journal of Chemistry, 9, 2, (2010) 292-296 http://dx.doi.org/10.22146/ijc.523

[8] Yongmei Xu, Yumin Du, Effect of molecular structure of chitosan on protein delivery properties of chitosan nanoparticles, International Journal of Pharmaceutics, 250, 1, (2003) 215-226 http://dx.doi.org/10.1016/S0378-5173(02)00548-3

[9] George A Jeffrey, George A Jeffrey, An introduction to hydrogen bonding, Oxford university press New York, 1997. 